\title{
COMUNICAÇÕES
}

\section{Ocorrência de Sclerotium rolfsii em plantas de kenaf no Estado de Pernambuco}

\author{
Íris Lettiere do Socorro Santos da Silva ${ }^{1}$, Péricles de Albuquerque Melo Filho ${ }^{1}$
}

\begin{abstract}
${ }^{1}$ Universidade Federal Rural de Pernambuco, Departamento de Agronomia, 52.171-900, Recife, PE, pericles@ ufrpe.br, irislletiere@ bol.com.br. Autor para correspondência: Péricles de Albuquerque Melo Filho

Data de chegada: 21/10/2005. Aceito para publicação em: 30/03/2006.
\end{abstract}

O kenaf (Hibiscus cannabinus L.) é uma planta anual herbácea, pertencente à família Malvaceae e cultivada no Egito há 6000 A.C. Teve origem no continente africano, sendo atualmente cultivada em países como a China, Tailândia, Índia, Estados Unidos e na América Latina. Trata-se de uma cultura importante para a indústria têxtil por fornecer grande quantidade de fibras de alta resistência, as quais, são utilizadas na confecção de tapetes, cordas, bolsas, papel, entre outros produtos. Tal propriedade a torna uma excelente alternativa em substituição à juta. $\mathrm{O}$ cultivo de kenaf vem aumentando mundialmente devido a seu ciclo curto e fornecimento de polpa clara empregada na indústria de papel. Isso tem dispensando o uso de ácidos clarificadores que são poluidores do meio ambiente. Além dessas utilidades, atribui-se ao kenaf a possibilidade de seu uso como fonte alimentar, fonte de produção de óleo e ainda, a possibilidade do seu emprego no tutoramento do inhame.

Em Pernambuco, o kenaf tem sido estudado para uso em programa de desenvolvimento sustentável e para controle de Aspergillus flavus em amendoim. Em uma área de plantio conduzida no Campus Experimental da Universidade Federal Rural de Pernambuco foi observada a presença de plantas doentes. Os sintomas iniciais foram o murchamento de plantas, seguido do estrangulamento na região do colo. Ainda no campo foi possível observar a presença de sinais do patógeno tais como: presença de escleródios claros, os quais se tornam marrom escuro e crescimento micelial de cor branco na área afetada.

O fungo foi isolado em meio de cultura BDA e identificado como Sclerotium rolfsii Sacc. A identificação tomou como base os caracteres morfológicos descritos para a espécie.

O teste de patogenicidade foi realizado com mudas de kenaf logo após a emissão da primeira folha definitiva. Escleródios e discos de micélio do fungo, cultivado em meio BDA, foram depositados sobre um ferimento no colo da planta, ocasionado por estilete flambado. $\mathrm{Na}$ testemunha, discos de BDA sem a presença do patógeno foram depositados sobre os ferimentos. Após a inoculação, as mudas foram submetidas a câmara úmida por 48 horas. Os primeiros sinais foram observados quatro dias após a inoculação, com a presença de micélio branco na região inoculada e posterior surgimento de escleródios (Figura 1). Os sintomas foram necrose no colo da planta, causando estrangulamento da região afetada (Figura 1) e murcha generalizada da planta. Para completar os postulados de Koch o fungo foi re-isolado das lesões produzidas e re-identificado como agente causal da doença. Em kenaf, a primeira ocorrência de Sclerotium rolfsii foi relatada em 2003 na África do Sul. No Brasil, esse é o primeiro relato.

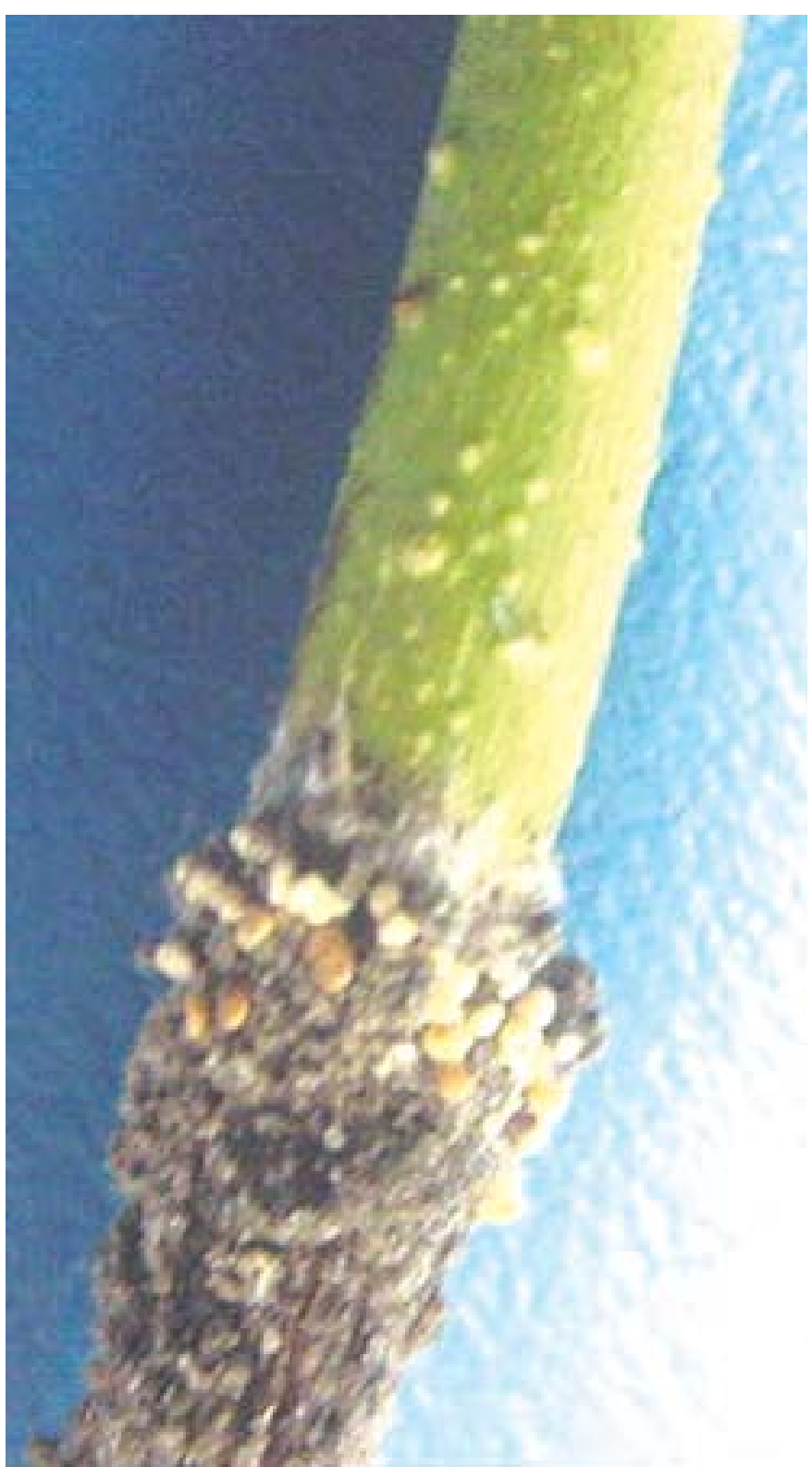

Figura 1. Sintomas e sinais de podridão do colo em Hibiscus cannabinus L. causados por Sclerotium rolfsii, mostrando presença de micélio branco, formação de escleródios e necrose do colo. 